\title{
Effects of Nitrogen and Potassium on Certain Agronomic and Chemical Characteristics of Samsun Tobacco in Greece*
}

\author{
by V. A. Mylonas, V. N. Athanasiadis and I. G. Sidiropoulos \\ Department of Agronomy, Tobacco Institute, Drama, Greece
}

\section{INTRODUCTION}

The amounts of major soil nutrients available markedly affect growth and development of the tobacco plant. Yield of Oriental tobacco is increased more pronouncedly with nitrogen than with any other nutrient. Todorovski (9) reported that the yield and profit of Otlja Oriental type tobacco increased when the rate of applied fertilizer (nitrogen - phosphorus - potassium $(3-5-8)$ ) increased from 0 to $1000 \mathrm{~kg} / \mathrm{ha}$. Lulov (4) suggested that for the Nevrokop tobacco growing area of Bulgaria, nitrogen must range from 30 to $60 \mathrm{~kg} / \mathrm{ha}$ and phosphorus from 60 to $120 \mathrm{~kg} / \mathrm{ha}$. Increasing the rate of nitrogen above $60 \mathrm{~kg} / \mathrm{ha}$ resulted in an increased yield but of lower quality. Shoumarski (7) reported that potassium at the rate of $66 \mathrm{~kg} / \mathrm{ha}$ increased the yield of Oriental tobacco, whereas a higher rate of $132 \mathrm{~kg} \mathrm{~K} / \mathrm{ha}$ had an adverse effect on yield.

Zulpiev (10) has shown that the yield of Samsun tobacco increased when the applied nitrogen increased from 45 to 90 and phosphorus from 40 to $80 \mathrm{~kg} / \mathrm{ha}$. However, a further increase of tested nutrients to $135 \mathrm{~kg} \mathrm{~N} / \mathrm{ha}$ and $120 \mathrm{~kg} \mathrm{P} / \mathrm{ha}$ did not affect the yield, whereas quality was lowered. Tariman (8), using four rates of nitrogen $(0,30,60$ and $90 \mathrm{~kg} / \mathrm{ha})$ and potassium $(0,100,200$ and $300 \mathrm{~kg} / \mathrm{ha}$ ), obtained the highest yield and best quality of Samsun tobacco with $30 \mathrm{~kg} \mathrm{~N} / \mathrm{ha}$ and $100 \mathrm{~kg} \mathrm{~K} / \mathrm{ha}$.

\footnotetext{
* Receired: 2nd January 1980 - accepted: 30th September 1980.
}

The objectives of this study were to measure the effects of nitrogen and potassium at four rates on the yield and quality of Samsun tobacco grown under the soil and climatic conditions of Katerini, Greece.

\section{MATERIALS AND METHODS}

Nicotiand tabacum L. (cv. Samsun 53) was grown for three years (1973-1975) at Katerini, Greece, in different fields each year. The fields used were those commonly used in rotation (tobacco - wheat - tobacco) for tobacco production by growers. The soils were alluvial (Entisol). There was no effort to select fields with specific levels of nutrients. This resulted in the use of a wide range of soil fertility levels. Prior to fertilizer application, soil samples were taken from the plow layer and analyzed (Table 1). Phosphorus was determined by Olsen's (6) procedure and potassium by Dirks' (2) procedure. Air temperature and rainfall for the period 1973-1975 are given in Table 2.

Table 1. Some characteristics of soils used.

\begin{tabular}{l|l|c|c|c|c}
\hline Year & $\begin{array}{c}\text { Textural } \\
\text { class }\end{array}$ & $\mathrm{pH}$ & $\begin{array}{c}\text { Organic } \\
\text { matter } \\
(\%)\end{array}$ & $\begin{array}{c}P \\
(\mathrm{ppm})\end{array}$ & $\begin{array}{c}K \\
(\mathrm{ppm})\end{array}$ \\
\hline 1973 & Sandy loam & 7.5 & 1.9 & 11.8 & 77 \\
1974 & Silty loam & 6.3 & 2.0 & 3.3 & 13 \\
1975 & Sandy loam & 6.4 & 1.3 & 8.5 & 23 \\
\hline
\end{tabular}


Table 2. Mean alr temperature and rainfall In Katerinl (average of three years (1973-1975)).

\begin{tabular}{|c|c|c|c|c|c|c|c|}
\hline \multirow{3}{*}{ Month } & \multicolumn{5}{|c|}{ Alr temperature $\left({ }^{\circ} \mathrm{C}\right)$} & \multicolumn{2}{|c|}{ Rainfall } \\
\hline & \multicolumn{2}{|c|}{ absolute } & \multicolumn{2}{|c|}{ mean } & \multirow{2}{*}{$\begin{array}{c}\text { average/ } \\
\text { day }\end{array}$} & \multirow{2}{*}{$\begin{array}{c}\text { height } \\
\text { (mm) }\end{array}$} & \multirow{2}{*}{ day: } \\
\hline & minimum & maximum & minimum & maximum & & & \\
\hline January & -7.0 & 15.5 & 1.4 & 8.6 & 5.6 & 67.2 & 7 \\
\hline February & -6.0 & 18.5 & 1.1 & 10.1 & 6.6 & 73.1 & 8 \\
\hline March & -4.5 & 21.5 & 3.5 & 12.7 & 9.1 & 79.6 & 9 \\
\hline April & 3.0 & 25.0 & 6.8 & 18.0 & 13.9 & 28.5 & 8 \\
\hline May & 3.5 & 34.0 & 11.7 & 23.8 & 19.6 & 28.3 & 7 \\
\hline June & 7.0 & 34.0 & 14.4 & 27.4 & 22.9 & 50.3 & 4 \\
\hline July & 12.0 & 40.0 & 17.4 & 31.1 & 25.8 & 18.6 & 4 \\
\hline August & 13.0 & 37.0 & 17.2 & 30.0 & 24.7 & 28.8 & 5 \\
\hline September & 9.0 & 33.0 & 15.5 & 27.0 & 21.9 & 48.2 & 5 \\
\hline October & $0: 3$ & 31.0 & 11.1 & 21.1 & 16.7 & 40.9 & 6 \\
\hline November & -5.5 & 19.0 & 4.8 & 13.8 & 10.7 & 129.3 & 8 \\
\hline December & -6.5 & $15: 0$ & 1.0 & 9.8 & 5.1 & 56.5 & 7 \\
\hline
\end{tabular}

Nitrogen was applied at rates of $20,40,60$ and $80 \mathrm{~kg} / \mathrm{ha}$ and potassium at rates of $30,60,90$ and $120 \mathrm{~kg} / \mathrm{ha}$. The rates were factorially combined and the resulting 16 treatments were replicated three times in a randomized complete block design. Phosphorus was applied at a uniform rate of $40 \mathrm{~kg} / \mathrm{ha}$. Seventy per cent of the nitrogen was in ammonium and $30 \%$ in nitrate form. The fertilizer nutrients were supplied from ammonium nitrate $(33.5 \% \mathrm{~N})$, ammonium sulfate $(21 \% \mathrm{~N})$, ordinary superphosphate $\left(21 \% \mathrm{P}_{2} \mathrm{O}_{5}\right)$ and potassium sulfate $(50 \%$ $\mathrm{K}_{2} \mathrm{O}$ ). Fertilizers were broadcast and incorporated into the soil to a depth of $15 \mathrm{~cm}$ about 3-5 days before transplanting. Plot sizes were 80,48 and $40 \mathrm{~m}^{2}$ in 1973 , 1974 and 1975, respectively, with two guard rows between the plots. Plant spacing between the rows was $40 \mathrm{~cm}$ and $12.5 \mathrm{~cm}$ within the rows. All cultural practices were in accordance with those used by the growers for Samsun tobacco production. Leaves were harvested in five primings and were sun-cured.

After curing, tobacco from each plot was sorted, weighed and graded. The value per hectare was calculated using the average market price for the appropriate grades. A composite sample from the five primings for each plot ( $5 \%$ of whole cured leaf from the entire plot) was used for chemical determinations. The quantity of tobacco per sample was about $1100 \mathrm{~g}$ in $1973,650 \mathrm{~g}$ in 1974 and $550 \mathrm{~g}$ in 1975. The samples were dried at $65^{\circ} \mathrm{C}$ for 72 hours and ground in a Wiley mill to pass through a $1 \mathrm{~mm}$ (16 mesh) sieve. Total alkaloids were determined by the Coresta $^{*}$ (1) procedure, total nitrogen by the Kjeldabl procedure, potassium by atomic emission and calcium and magnesium by atomic absorption in a Perkin-Elmer 403 spectrophotometer. Burning capacity was measured on the ground sample by the following procedure. A certain volume of ground tobacco $(5 \mathrm{~g})$ that passed through a $0.354 \mathrm{~mm}$ (42 mesh) sieve was equilibrated for 24 hours at $50^{\circ} \mathrm{C}$ to a moisture content of $2.5 \%$, and then placed

* Cooperation Centre for Scientific Research relative to Tobacco in a channel $5 \mathrm{~mm}$ wide $\times 5 \mathrm{~mm}$ deep $\times 200 \mathrm{~mm}$ long made of glass rods. One end was ignited and the rate of burning $(\mathrm{mm} / \mathrm{min})$ of the tobacco was recorded. Data from each individual experiment were evaluated with an analysis of variance. The error mean squares for each characteristic studied were then compared using Bartlett's test for homogeneity of variances. As a result data were combined over the three years.

\section{RESULTS AND DISCUSSION}

Since the interactions between nitrogen and potassium for determined characteristics were not significant, only the mean values of nitrogen rates over potassium and the mean values of potassium rates over nitrogen are presented.

The effect of nitrogen and potassium fertilization on yield, value/ha and burning capacity of Samsun tobacco are shown in Table 3. Leaf yield increased significantly as applied nitrogen increased from 20 to $40 \mathrm{~kg} / \mathrm{ha}$, whereas further increase of nitrogen to $60 \mathrm{~kg} / \mathrm{ha}$ resulted in an insignificant increase in leaf yield. There was a tendency for value/ha of tobacco to increase as nitrogen increased from 20 to $40 \mathrm{~kg} / \mathrm{ha}$. A further increase of nitrogen to 60 and $80 \mathrm{~kg} / \mathrm{ha}$ tended to decrease the value/ha of tobacco. Leaf yield and market value tended to increase as potassium fertilization increased from 30 to $60 \mathrm{~kg} / \mathrm{ha}$, beyond which no further increase occurred.

General observations in the field during the course of the experiments suggested that as nitrogen increased from 20 to $80 \mathrm{~kg} / \mathrm{ha}$ the height of the plants and leaf area increased, whereas the color of leaves changed from yellowgreen to dark green. The lowest rate of nitrogen $(20 \mathrm{~kg} / \mathrm{ha})$ produced short plants with small, thin leaves showing symptoms of nitrogen deficiency. When cured, these leaves were pale in color and lacked the desired textural properties associated with high quality tobacco. 
Table 3. Effect of nitrogen and potassium on yleld, value and burning capacity of Samsun tobacco (average of three years).

\begin{tabular}{|c|c|c|c|}
\hline $\begin{array}{l}\text { Nutrient } \\
\text { rate } \\
\text { (kg/ha) }\end{array}$ & $\begin{array}{l}\text { Yield } \\
\text { (kg/ha) }\end{array}$ & $\begin{array}{l}\text { Value } \\
\text { (\$/ha) }\end{array}$ & $\begin{array}{c}\text { Burning } \\
\text { capacity } \\
(\mathrm{mm} / \mathrm{m} / \mathrm{n})\end{array}$ \\
\hline \multicolumn{4}{|l|}{ Nitrogen $(N)$} \\
\hline 20 & 2507 & 7376 & 3.96 \\
\hline 40 & 2721 & 7667 & 4.26 \\
\hline 60 & 2794 & 7362 & 4.41 \\
\hline 80 & 2806 & 6968 & 4.52 \\
\hline $\begin{array}{l}\text { Least significant } \\
\text { difference }(p=0.05)\end{array}$ & 145 & n.s. * & 0.41 \\
\hline \multicolumn{4}{|l|}{ Potassium (K) } \\
\hline 30 & 2657 & 7129 & 4.25 \\
\hline 60 & 2730 & 7406 & 4.23 \\
\hline 90 & 2719 & 7341 & 4.30 \\
\hline 120 & 2722 & 7497 & 4.36 \\
\hline $\begin{array}{l}\text { Least significant } \\
\text { difference }(p=0.05)\end{array}$ & n.s. & n.s. & n.s. \\
\hline
\end{tabular}

" not significant

The rate of $40 \mathrm{~kg} \mathrm{~N} / \mathrm{ha}$ produced good sized leaves, light orange in color with very good elasticity, thickness and body. This rate of nitrogen greatly improved the visual characteristics of cured leaves over the rate of $20 \mathrm{~kg} \mathrm{~N} / \mathrm{ha}$. From these observations it may be concluded that the rate of $20 \mathrm{~kg} \mathrm{~N} / \mathrm{ha}$ supplied inadequate nitrogen for good plant growth. Calculating the price of tobacco produced with $20 \mathrm{~kg} \mathrm{~N} / \mathrm{ha}$ and $40 \mathrm{~kg} \mathrm{~N} / \mathrm{ha}$, we observed that the price of tobacco of $20 \mathrm{~kg} \mathrm{~N} / \mathrm{ha}$ is a little higher than the price of tobacco of $40 \mathrm{~kg} \mathrm{~N} / \mathrm{ha}$. This is explained by the traditional tendency to produce tobacco with small leaves. But the best quality is not always associated with very small leaves. The rate of $80 \mathrm{~kg} \mathrm{~N} / \mathrm{ha}$ produced large leaves, dark orange in color and with decreased elasticity and body. These characteristics made the quality of the cured leaves less than desirable for manufactured products.

Tobacco burning capacity increased significantly as nitrogen increased from 20 to $80 \mathrm{~kg} / \mathrm{ha}$. The increased application of nitrogen increased leaf area and resulted in a thinner cured leaf. Since a thin leaf usually has better burning qualities than a thick, close-textured one, the increased nitrogen fertilization favourably affects the combustibility of tobacco, although high concentrations of nitrogen in the leaf tend to reduce combustibility (5) due to the difficulty of combustion of proteins and related nitrogen compounds. Potassium fertilization tended to increase burning capacity.

Table 4 shows the influence of nitrogen and potassium on certain chemical characteristics of cured Samsun tobacco. Generally, the percentage of total alkaloids and total nitrogen in the whole cured leaf increased significantly when the rate of nitrogen increased from 20 to $80 \mathrm{~kg} / \mathrm{ha}$. The differences of total alkaloids and total nitrogen among the rates of applied nitrogen were
Table 4. Effect of nitrogen and potassium on chemical composition of Samsun tobacco (average of three years).

\begin{tabular}{c|c|c|c|c|c}
\hline $\begin{array}{c}\text { Nutrlent } \\
\text { rate } \\
(\mathrm{kg} / \mathrm{ha})\end{array}$ & $\begin{array}{c}\text { Total } \\
\text { alkaloids } \\
(\%)\end{array}$ & $\begin{array}{c}\text { Total } \\
\mathrm{N} \\
(\%)\end{array}$ & $\begin{array}{c}\mathrm{K} \\
(\%)\end{array}$ & $\begin{array}{c}\mathrm{Ca} \\
(\%)\end{array}$ & $\begin{array}{c}\mathrm{Mg} \\
(\%)\end{array}$ \\
\hline Nitrogen $(\mathrm{N})$ & & & & & \\
20 & 1.49 & 2.11 & 2.97 & 2.44 & 0.56 \\
40 & 1.51 & 2.21 & 3.05 & 2.60 & 0.57 \\
60 & 1.61 & 2.34 & 3.09 & 2.73 & 0.61 \\
80 & 1.78 & 2.52 & 3.16 & 2.83 & 0.62 \\
& & & & & \\
Least significant 0.08 & 0.11 & 0.13 & 0.17 & 0.05 \\
difference (p =0.05) & & & &
\end{tabular}

$\begin{array}{cccccc}\begin{array}{c}\text { Potassium (K) } \\ 30\end{array} & 1.65 & 2.32 & 2.96 & 2.64 & 0.62 \\ 60 & 1.59 & 2.30 & 3.07 & 2.67 & 0.59 \\ 90 & 1.59 & 2.29 & 3.08 & 2.65 & 0.60 \\ 120 & 1.57 & 2.27 & 3.16 & 2.63 & 0.58 \\ \begin{array}{l}\text { Least significant } \\ \text { difference (p=0.05) }\end{array} & \text { n.s." } & \text { n.s. } & 0.12 & \text { n.s. } & 0.03\end{array}$

- not significant

relatively small. When nitrogen increased from 20 to $60 \mathrm{~kg} / \mathrm{ha}$, total alkaloids increased by $8 \%$ and total $\mathrm{ni}-$ trogen by $15 \%$. Nitrogen is considered to be a dominant factor which influences the level of strength in tobacco smoke.

There was a tendency for the percentage of leaf potassium to increase as nitrogen fertilization increased from 20 to $80 \mathrm{~kg} / \mathrm{ha}$. This indicates that the increased availability of soil nitrogen affects the uptake of other nutrients such as potassium, calcium and magnesium. The percentage of leaf calcium increased significantly as the rate of nitrogen increased from 20 to $60 \mathrm{~kg} / \mathrm{ha}$, whereas a further increase of nitrogen to $80 \mathrm{~kg} / \mathrm{ha}$ resulted in an insignificant increase in calcium concentration. Leaf magnesium concentration tended to increase as applied nitrogen increased. The higher calcium and magnesium concentration in cured leaves with increasing nitrogen rate may be related to preferential uptake of $\mathrm{NO}_{3}-$ compared to $\mathrm{NH}_{4}-$ nitrogen uptake from soil and probably to a higher concentration of organic acids. The $\mathrm{NO}_{3}-$ concentration in cured leaves increased with an increasing nitrogen rate (3).

There was a tendency for the percentage of total alkaloids and total nitrogen in the leaf (Table 4) to decrease as applied potassium increased. This decrease was very small but indicated that potassium fertilization may balance some detrimental effects of nitrogen fertilization on tobacco quality.

Generally, the concentration of leaf potassium tended to increase as the rate of potassium increased from 30 to $120 \mathrm{~kg} \mathrm{~K} / \mathrm{ha}$. The soil potassium varied from field to field. The field used in 1973 had the highest value of available potassium (Table 1), while the field used in 1974 had the lowest value of available potassium. Evaluating the data of potassium concentration in the cured leaf for each crop year, we concluded that the effect of increased 
potassium fertilization was more pronounced in 1974 that in 1975 and in 1973. This indicates that this effect of potassium fertilization was higher when the available soil potassium was lower. The rates of potassium used had no effect on calcium concentration (Table 4). Magnesium concentration tended to decrease as applied potassium increased.

\section{SUMMARY}

Field experiments were conducted in 1973-1975 at Katerini, Greece, to determine the effects of nitrogen and potassium fertilization rates on the yield, value and chemical composition of Samsun tobacco (Nicotiana tabacum L. (cv. Samsun 53)) leaves. Nitrogen was applied at rates of $20,40,60$ and $80 \mathrm{~kg} / \mathrm{ha}$ and potassium at rates of $30,60,90$ and $120 \mathrm{~kg} / \mathrm{ha}$.

Leaf yield increased significantly as applied nitrogen increased from 20 to $40 \mathrm{~kg} / \mathrm{ha}$, whereas further increase of nitrogen to 60 or to $80 \mathrm{~kg} /$ ha resulted in an insignificant increase in leaf yield. There was a tendency for value/ha of tobacco to increase as nitrogen rate increased from 20 to $40 \mathrm{~kg} / \mathrm{ha}$. A further increase of nitrogen to 60 and $80 \mathrm{~kg} / \mathrm{ha}$ tended to decrease the value of tobacco. Generally, burning capacity and percentage of total alkaloids, total nitrogen, calcium and magnesium increased significantly as applied nitrogen increased. Percentage leaf potassium tended to increase as rate of nitrogen increased.

Leaf yield and value/ha tended to increase as applied potassium increased from 30 to $60 \mathrm{~kg} / \mathrm{ha}$, beyond which no further increase occurred. Burning capacity and concentration of leaf potassium tended to increase, whereas the percentage of total alkaloids and magnesium tended to decrease as the rate of potassium increased. Concentrations of nitrogen and calcium were not affected by potassium rates.

Generally, for production of a good yield and quality of Samsun tobacco in soils similar to that of Katerini, Greece, the rate of applied nitrogen should be higher than $20 \mathrm{~kg} / \mathrm{ha}$ but lower than $60 \mathrm{~kg} / \mathrm{ha}$, while the rate of applied potassium should be above $30 \mathrm{~kg} / \mathrm{ha}$ and up to $90 \mathrm{~kg} / \mathrm{ha}$.

\section{ZUSAMMENFASSUNG}

Zur Untersuchung des Einflusses der Düngung mit unterschiedlichen Stickstoff- und Kaliumgaben auf den Ertrag, den Marktwert und die chemische Zusammensetzung von Samsun-Tabak (Nicotiana tabacum L. (Sorte Samsun 53)) wurden in den Jahren 1973 bis 1975 in Katerini/Griechenland Feldversuche durdigeführt. Stickstoff wurde in den Mengen 20,40,60 und $80 \mathrm{~kg} / \mathrm{ha}$ und Kalium in den Mengen $30,60,90$ und $120 \mathrm{~kg} / \mathrm{ha}$ gegeben.

Bei einer Erhöhung der Stickstoffmenge von $20 \mathrm{~kg} / \mathrm{ha}$ auf $40 \mathrm{~kg} / \mathrm{ha}$ stieg der Blattertrag signifikant an, während er bei weiterer Steigerung auf $60 \mathrm{~kg} / \mathrm{ha}$ oder
$80 \mathrm{~kg} / \mathrm{ha}$ nur unerheblich zunahm. Der Marktwert je Hektar Tabak stieg mit der Erhöhung der Stickstoffgabe von $20 \mathrm{~kg} / \mathrm{ha}$ auf $40 \mathrm{~kg} / \mathrm{ha}$ an und nahm bei weiterer Steigerung auf $60 \mathrm{~kg} / \mathrm{ha}$ und $80 \mathrm{~kg} / \mathrm{ha}$ ab. Mit zunehmender Stickstoffmenge erhöhte sich im allgemeinen die Brennbarkeit und der Gehalt an Gesamtalkaloiden, Gesamtstidkstoff, Calcium und Magnesium signifikant; auch wurde die Tendenz eines Anstiegs des Kaliumgehaltes des Blattgutes bei zunehmender Stickstoffgabe beobachtet.

Wurde die Kaliumgabe von $30 \mathrm{~kg} / \mathrm{ha}$ auf $60 \mathrm{~kg} / \mathrm{ha}$ angehoben, so erhöhten sich Blattertrag und Marktwert je Hektar; eine weitere Anhebung der Kaliumgabe erbrachte jedoch keine weitere Zunahme. Mit steigender Kaliumgabe zeigten Brennbarkeit und Kaliumgehalt des Blattgutes eine zunehmende, der Gehalt an Gesamtalkaloiden und Magnesium hingegen eine abnehmende Tendenz. Der Gehalt an Stickstoff und Calcium wurde durch die Kaliummenge nicht beeinflußt.

Allgemein ist festzustellen, daß beim Samsun-Tabak zur Erzielung eines guten Ertrages und guter Qualität bei Bodenverhältnissen ähnlid denen von Katerini/Griechenland die Stickstoffgabe über $20 \mathrm{~kg} / \mathrm{ha}$ liegen, aber $60 \mathrm{~kg} / \mathrm{ha}$ nidht übersteigen und die Kaliumgabe zwischen $30 \mathrm{~kg} / \mathrm{ha}$ und $90 \mathrm{~kg} / \mathrm{ha}$ liegen sollte.

\section{RESUME}

Des expériences agricoles ont été effectuées de 1973 à 1975 à Katerini, en Grèce, afin de déterminer l'influence de diverses doses d'azote et de potassium sur le rendement, la valeur et la composition chimique des feuilles de tabac Samsun (Nicotiana tabacum L. (variété Samsun 53)). L'azote a été appliqué en doses de 20,40, 60 et $80 \mathrm{~kg} / \mathrm{ha}$ et le potassium en doses de 30,60 , 90 et $120 \mathrm{~kg} / \mathrm{ha}$.

L'accroissement du rendement a été considérable avec l'augmentation de l'apport d'azote de 20 à $40 \mathrm{~kg} / \mathrm{ha}$, alors qu'une augmentation d̀ $60 \mathrm{ou} 80 \mathrm{~kg}$ n'a provoqué qu'une faible augmentation du rendement. $\mathrm{La}$ valeur à l'hectare du tabac a augmenté avec l'augmentation de l'apport d'azote de $20 \mathrm{a} 40 \mathrm{~kg} / \mathrm{ha}$, mais elle a diminué avec les doses plus élevées de 60 et $80 \mathrm{~kg} / \mathrm{ha}$. En général, la combustibilité et la teneur en alcaloìdes totaux, de l'azote total, du calcium et du magnésium de la feuille a augmenté de façon significative avec l'augmentation de l'apport d'azote, alors que le potassium manifestait une tendance à l'augmentation.

L'accroissement de l'apport en potassium de 30 à $60 \mathrm{~kg} / \mathrm{ha}$ a fait augmenter le rendement et la valeur a l'hectare des feuilles. Un apport plus élevé en potassium n'a plus entraîné d'amélioration. Avec l'accroissement des doses de potassium, la combustibilité ainsi que la teneur en potassium des feuilles ont eu tendance $a$ augmenter alors que la teneur en alcaloîdes totaux et en magnésium accusaient une tendance contraire. La teneur en azote et en calcium n'a pas été influencée par le taux de potassium. 
En général, pour obtenir un bon rendement ainsi qu'une bonne qualité de tabac «Samsun* dans des sols similaires a ceux de Katerini, la dose d'azote à appliquer doit être supérieure à $20 \mathrm{~kg} / \mathrm{ha}$ mais inférieure d̀ $60 \mathrm{~kg} / \mathrm{ha}$ alors que la dose de potassium devait être comprise entre 30 et $90 \mathrm{~kg} / \mathrm{ha}$.

\section{REFERENCES}

1. Coresta Standard Method No. 20: Determination of alkaloids in manufactured tobacco; Coresta Inf. Bull. 1969-2, 25-27.

2. Dirks, B., and F. Scheffer: $Z$. Pflanzenern., Düngung und Bodenk. 1933, 428.

3. Fuqua, B. D., J. L. Sims, J. E. Leggett, J. F. Berner and W. O. Atkinson: Nitrate and chloride fertilization effects on yield and chemical composition of Burley tobacco leaves and smoke; Can. J. Plant Sci. 56 (1976) 893-899.

4. Lulov, K. B.: Agrotechnics of Nevrokop 261 tobacco variety in Nevrokop area; Nauchni Trud., Plovdiv, 1974-4, 91-106.

5. McCants, C. B., and W. G. Woltz: Growth and mineral nutrition of tobacco; Advances in Agronomy 19 (1967) 211-265.

6. Olsen, S. R., C. V. Cole, F. S. Watanabe and I. A. Dean: Estimation of available phosphorus in soils by extraction with sodium bicarbonate; U.S. Dept. Agr. Circ. 939, 1954.
7. Shoumarski, N.: Fertilizer application to Oriental tobacco; Bulg. Tyutyum 18 (1973) 25-29.

8. Tariman, C., and Y. M. Majumder: Effects of nitrogenous and potassium fertilizers on the yield and quality of Samsun Maden tobacco variety (Nicotiana tabacum); Bangladesh J. Sci. (Ind. Res.) 12 (1977) 81-90.

9. Todorovski, P. J.: Influence of increasing rates of nitrogen, phosphate and potassium fertilizers on the yield and quality of Otlja type tobacco; 5th Int. Tob. Sci. Congr. (Proc.), Hamburg, 1970, 176.

10. Zulpiev, T., B. Atyshev and A. Kurbanaliev: Botanical variety, fertilizer, tobacco yield and quality; Tabak, USSR, 1971-4, 11-13.

\section{Acknowledgements}

Thanks are expressed to the Department of Chemistry of the Tobacco Institute of Greece for alkaloids, nitrogen and burning capacity determinations and to P. Margioridou, K. Papadopoulos and N. Tsakiris for tednical assistance.

Autbors' address:

Department of Agronomy, Tobacco Institute, Drama, Greece. 